\title{
Studies on the Alkylation of 5'-CMP under Alkaline Conditions
}

\author{
Khurshid Alam Khan* and M. Qudrat-e-Khuda \\ Pakistan Council of Scientific and Industrial Research Laboratories Complex, \\ Karachi-75280, Pakistan \\ Viqar Uddin Ahmad \\ H. E. J. Research Institute of Chemistry, University of Karachi, Karachi-75270, Pakistan \\ Z. Naturforsch. 47b, 1307-1313 (1992); received February 27, 1992 \\ Nucleotides, Ribose Alkylated Products, ${ }^{1} \mathrm{H}$ NMR Spectra \\ The reaction of 5'-CMP with methyl, ethyl, $n$-propyl and isopropyl iodides gave predomi- \\ nantly ribose alkylated products. Various alkylated derivatives have been characterized using \\ UV spectroscopy, paper electrophoresis, ${ }^{1} \mathrm{H}$ NMR and FAB (negative) mass spectroscopic \\ techniques. Under strongly alkaline conditions the 2 '-O-alkylated derivatives are synthesized \\ in maximal yields. Isopropylation reaction gave only a small yield of the 3'-O-isopropyl deriva- \\ tive, this could be explained on the basis of steric hindrance offered to the bulky isopropyl \\ group at the $2^{\prime}-\mathrm{OH}$ position by the heterocyclic base of the nucleotide.
}

\section{Introduction}

Nucleotides methylated at the 2'-hydroxyl of ribose are of widespread occurrence as minor constituents of transfer and ribosomal RNAs of a variety of living organisms [1]. Various methylating agents are cytotoxic due to the alkylation of DNA bases produced by them [2]. The 2'-O-ethylated nucleotides were detected in the $t$-RNA of L-ethionine induced carcinoma [3, 4].

Many 2'-O-methylated and ethylated homopolynucleotides have been synthesized [5-7] and their properties reported; recently 2'-O-methylated oligonucleotides of defined sequences have also been prepared for use as probes in RNA hybridization studies [8]. In the above mentioned studies, generally the unprotected nucleoside has been alkylated, the various alkylated isomers were separated and the 2'-O-alkylated nucleoside was subsequently converted to the nucleotide by conventional phosphorylation methods. The studies on the direct alkylation of unprotected nucleotides leading to ribose alkylated derivatives are few; the ready availability of alkyl iodides and the reports [10] that under strongly alkaline conditions the alkylation of heterocyclic ring is minimized while the vicinal hydroxyls of ribose are slightly ionized prompted us to study the alkylation of $5^{\prime}$-CMP

\footnotetext{
* Reprint requests to Dr. K. A. Khan.

Verlag der Zeitschrift für Naturforschung, D-W-7400 Tübingen

0932-0776/92/0900-1307/\$01.00/0
}

with methyl, ethyl, normal and iso-propyl iodides under strongly alkaline conditions. The results obtained from these studies are being presented in this publication. It is hoped that the availability of nucleotides containing a wide range of alkyl groups at the ribose will lead to further studies on the effect of these groups on polynucleotide conformations, for preparation of oligonucleotides of defined sequences and for evaluation as inhibitors of enzymes responsible for nucleic acid metabolism.

\section{Results and Discussion}

A literature survey indicated that reaction conditions play a decisive role on the site of alkylation in nucleotides. Thus, Haines [11] et al. carried out a comparative study of the methylation of unprotected nucleotides using diazomethane and dimethyl sulphate in aqueous medium and at $\mathrm{pH} 5-7$ reported, in case of 5'-CMP, formation of phosphate ester together with products containing 1-methyl-5'-CMP and its corresponding ester.

The reaction of 5'-CMP 1 was carried out for three hours using methyl iodide in a mixture of dioxane and $1 \mathrm{~N}$ sodium hydroxide at room temperature. Paper chromatography of the crude reaction mixture revealed the formation of new products of higher mobilities as compared to the starting material (Table I). The products were separated by preparative paper chromatography on $3 \mathrm{MM}$ Whatman chromatography sheets by using solvent A. Starting from known nucleotides it 


\begin{tabular}{|c|c|c|c|c|c|}
\hline \multirow[t]{2}{*}{ Compound } & \multicolumn{3}{|c|}{$R_{f}$ in solvent systems } & \multicolumn{2}{|c|}{$\begin{array}{l}\text { Paper electrophoresis } \\
\text { (migration in } \mathrm{cm})\end{array}$} \\
\hline & $\mathrm{A}^{\prime}$ & $\mathrm{B}$ & & $\begin{array}{l}\text { (migratic } \\
\text { Buffer I }\end{array}$ & Buffer II \\
\hline $5^{\prime}-\mathrm{CMP} 1$ & 0.08 & 0.26 & 0.49 & 9.0 & 4.0 \\
\hline $\mathrm{N}^{3}$-Methyl-5'-CMP 2 & 0.21 & 0.59 & 0.65 & 4.8 & 4.0 \\
\hline $2^{\prime}, 3^{\prime}$-Di-O-methyl-5'-CMP 3 & 0.26 & 0.69 & 0.72 & 9.5 & 4.0 \\
\hline $2^{\prime}-\mathrm{O}-\mathrm{Methyl}-5^{\prime}-\mathrm{CMP} 4$ & 0.15 & 0.49 & 0.62 & 9.0 & 4.1 \\
\hline 3'-O-Methyl-5'-CMP 5 & 0.12 & 0.45 & 0.58 & 9.0 & 4.0 \\
\hline $2^{\prime}, 3^{\prime}-\mathrm{Di}-\mathrm{O}-\mathrm{ethyl}-5^{\prime}-\mathrm{CMP} 6$ & 0.71 & 0,85 & 0.88 & 9.1 & 4.0 \\
\hline $2^{\prime}-\mathrm{O}-$ Ethyl-5'-CMP 7 & 0.13 & 0.51 & 0.47 & 9.0 & 4.0 \\
\hline $3^{\prime}-\mathrm{O}-$ Ethyl-5'-CMP 8 & 0.22 & 0.61 & 0.71 & 9.1 & 4.2 \\
\hline $\mathrm{N}^{3}, 2^{\prime}-\mathrm{O}-\mathrm{Di}-n$-propyl-5'-CMP 9 & 0.48 & 0.78 & 0.70 & 5.0 & 4.2 \\
\hline $2^{\prime}, 3^{\prime}-\mathrm{Di}-\mathrm{O}-n$-propyl-5'-CMP 10 & 0.45 & 0.69 & 0.45 & 9.2 & 4.1 \\
\hline $2^{\prime}-\mathrm{O}-n$-Propyl-5'-CMP 11 & 0.12 & 0.34 & 0.31 & 9.0 & 4.0 \\
\hline 3'-O-Isopropyl-5'-CMP 12 & 0.23 & 0.66 & 0.65 & 9.2 & 4.2 \\
\hline
\end{tabular}

Table I. Paper electrophoresis and paper chromatography of alkylated nucleotides. is possible to assign the structure of nucleotide derivatives by a combination of UV spectroscopy, paper electrophoresis, ${ }^{1} \mathrm{H}$ NMR spectroscopy and FAB (negative) mass spectroscopy. Any perturbation of UV spectrum from that of the unsubstituted nucleotide is suggestive of a substitution at the base moiety [13]. The shift of the anomeric proton of ribose to a lower field as compared to that of unsubstituted nucleoside or nucleotide is indicative of ribose substitution, the 2'-O-substitution being at a lower field as compared to $3^{\prime}$-O-substitution [14]. The presence of phosphate group can be ascertained by the deshielding of $\mathrm{H}-6$ proton of cytidine by phosphate group while the phosphate alkylation can be determined by paper electrophoresis [15] at $\mathrm{pH} 8.5$ and $\mathrm{pH} \mathrm{4.7;} \mathrm{at} \mathrm{the} \mathrm{form-}$ er $\mathrm{pH}$ the migration of monoanion is half that of dianion. Nucleotides are generally not amenable to mass spectrometry, unless derivatized, due to their highly polar nature. However, with the introduction of FAB mass spectrometry especially in the negative mode [17], it is now possible to determine the molecular composition of nucleotides routinely. In the present work this technique has been successfully applied to determine the molecular composition of the alkylated nucleotides, the details of mass spectral measurements will be published elsewhere.

From the reaction of $5^{\prime}$-CMP with methyl iodide the product corresponding to $R_{f} 0.21$ in solvent $\mathrm{A}$ (Table I) was obtained in $18.8 \%$ yield and showed a shift of $\lambda_{\max }$ to lower wave length at both acidic and basic pH (Table II), this shift corresponded in magnitude to that of an $\mathrm{N}^{3}$ substituted cytidine moiety $[11,12]$. The electrophoretic mobility of the compound at $\mathrm{pH} 8.0$ was also less than

\begin{tabular}{|c|c|c|c|c|c|c|}
\hline \multirow[t]{2}{*}{ Compound } & \multicolumn{2}{|c|}{$\lambda_{\max }(\mathrm{nm})$} & \multicolumn{2}{|c|}{$\lambda_{\min }(\mathrm{nm})$} & \multicolumn{2}{|c|}{$\begin{array}{l}\text { Extinction } \\
\text { coefficient } \\
\left(\varepsilon \times 10^{-3}\right)\end{array}$} \\
\hline & $\mathrm{pH} 2$ & $\mathrm{pH} 12$ & pH 2 & $\mathrm{pH} 12$ & $\mathrm{pH} 2$ & $\mathrm{pH} 12$ \\
\hline $5^{\prime}-\mathrm{CMP} 1$ & 280 & 271 & 240 & 250 & 13.0 & 8.0 \\
\hline $\mathrm{N}^{3}$-Methyl-5'-CMP 2 & 276 & 266 & 240 & 250 & 13.3 & 10.5 \\
\hline 2',3'-Di-O-methyl-5'-CMP 3 & 280 & 270 & 240 & 250 & 13.4 & 12.6 \\
\hline 2'-O-Methyl-5'-CMP 4 & 280 & 270 & 240 & 250 & 11.4 & 7.0 \\
\hline 3'-O-Methyl-5'-CMP 5 & 280 & 270 & 242 & 250 & 10.9 & 7.0 \\
\hline $2^{\prime}, 3^{\prime}$-Di-O-ethyl-5'-CMP 6 & 279 & 269 & 240 & 250 & 10.8 & 9.1 \\
\hline 2'-O-Ethyl-5'-CMP 7 & 279 & 269 & 240 & 250 & 12.4 & 11.2 \\
\hline 3'-O-Ethyl-5'-CMP 8 & 279 & 269 & 240 & 250 & 10.5 & 10.1 \\
\hline $\mathrm{N}^{3}, 2^{\prime}$-Di-O-n-propyl-5'-CMP 9 & 276 & 266 & 240 & 250 & 14.2 & 13.3 \\
\hline $2^{\prime}, 3^{\prime}$-Di-O-n-propyl-5'-CMP 10 & 278 & 270 & 240 & 250 & 14.1 & 11.1 \\
\hline $2^{\prime}-\mathrm{O}-n$-Propyl-5'-CMP 11 & 279 & 270 & 240 & 250 & 15.9 & 12.3 \\
\hline 3'-O-Isopropyl-5'-CMP 12 & 278 & 269 & 240 & 250 & 13.8 & 12.1 \\
\hline
\end{tabular}

Table II. Ultra-violet spectral data of alkylated 5'-CMP derivatives. 
that of 5'-CMP [12] (Table I) indicating an $\mathrm{N}^{3}$ alkylation. The ${ }^{1} \mathrm{H}$ NMR spectrum exhibited a singlet at $\delta 3.32$ integrating for three protons. The UV spectral shift as well as the location of methyl signals in the ${ }^{1} \mathrm{H}$ NMR spectrum indicated an $\mathrm{N}^{3}$ substitution and therefore the product was assigned as $\mathrm{N}^{3}$-methyl-5'-CMP 2.

The product corresponding to $R_{f} 0.26$ in solvent A was obtained in $19.1 \%$ yield and did not show alkylation at the base or phosphate groups as judged by the similarity of UV and electrophoretic data with the parent compound (Table I, II). The ${ }^{1} \mathrm{H}$ NMR spectrum in $\mathrm{D}_{2} \mathrm{O}$ exhibited the $\mathrm{H}-5, \mathrm{H}-6$ and $\mathrm{H}-1^{\prime}$ signals as doublets at expected $\delta$ values (see experimental part). Two singlets integrating for three protons each were located at $\delta 3.52$ and 3.41 , and were assigned to $2^{\prime}-\mathrm{O}$ - and 3 '-O-methyl groups respectively. These values are in agreement with those reported for 2'-O- and 3'-O-methyl signals of cytidine [16]. The structure of this product was therefore assigned as $2^{\prime}, 3^{\prime}$-Di-O-methyl-5' CMP 3. The structure was further confirmed by FAB (negative) mass spectrum which exhibited molecular ion [M-H] at $m / z 350$ corresponding to the correct molecular formula $\mathrm{C}_{11} \mathrm{H}_{17} \mathrm{~N}_{3} \mathrm{O}_{8} \mathrm{P}$.

The product corresponding to $R_{f} 0.15$ was obtained in $38.3 \%$ yield, its UV spectrum was similar to 5'-CMP (Table II) and so was its electrophoretic mobility at $\mathrm{pH} 8.5$ indicating the absence of alkylation at the base and phosphate moieties. The anomeric proton of ribose was located at $\delta 6.03$ and was shifted downfield as compared to the anomeric proton of $5^{\prime}$-CMP which was located at $\delta 5.98$ at identical concentration; this downfield displacement suggested alkylation of $2^{\prime}-\mathrm{OH}$ of ribose. The singlet of methyl protons was located at $\delta 3.52$ substantiating the assignment. FAB (negative) mass spectrum exhibited molecular ion $[\mathrm{M}-\mathrm{H}]$ at $\mathrm{m} / \mathrm{z} 336$ corresponding to correct molecular formula $\mathrm{C}_{10} \mathrm{H}_{15} \mathrm{~N}_{3} \mathrm{O}_{8} \mathrm{P}$. This compound was therefore characterized as 2'-O-methyl-5'-CMP 4.

The product corresponding to $R_{f} 0.12$ in solvent A was obtained in $11.5 \%$ yield, its UV spectrum and electrophoretic mobility were similar to $5^{\prime}$ CMP, excluding substitution at base and phosphate moieties. The ${ }^{1} \mathrm{H}$ NMR spectrum of the product exhibited the anomeric proton at $\delta 5.72$ which is shifted upfield as compared to the $\mathrm{H}-\mathrm{1}^{\prime}$ of 5 '-CMP indicating alkylation at $3^{\prime}-\mathrm{OH}$ group ribose; furthermore a singlet integrating for three methyl protons was observed at $\delta 3.41$. The FAB (negative) mass exhibited molecular ion $[\mathrm{M}-\mathrm{H}]$ at $\mathrm{m} / \mathrm{z} 380$ corresponding to molecular formula $\mathrm{C}_{10} \mathrm{H}_{13} \mathrm{~N}_{3} \mathrm{O}_{8} \mathrm{PNa}_{2}$, the product was therefore characterized as 3'-O-methyl-5'-CMP disodium salt 5.

The reaction of $5^{\prime}$-CMP with ethyl iodide was carried out similar to methylation except that the reaction was done at $60{ }^{\circ} \mathrm{C}$ for optimum yields. The product of $R_{f} 0.71$ in solvent A (Table I), was obtained in $21.1 \%$ yield; its UV spectrum (Table II) and electrophoretic mobility were similar to 5'-CMP, therefore alkylation at base and phosphate moieties was excluded. The ${ }^{1} \mathrm{H}$ NMR spectrum of the compound exhibited the protons $\mathrm{H}-5, \mathrm{H}-6$ and $\mathrm{H}-1^{\prime}$ at expected $\delta$ values (experimental part). The ethyl signals were located at $\delta 1.15$ as two triplets, each integrating for three protons, and were ascribed to two methyl groups. A multiplet at $\delta 3.65$ integrating for four protons, was ascribable to two methylenes of the ethyl groups; this indicated the presence of two ethyl groups at the 2'-O- and 3'-O-hydroxyls of ribose. The compound was therefore assigned as $2^{\prime}, 3^{\prime}$ Di-O-ethyl-5'-CMP 6. The structure is supported by FAB mass in the negative mode which exhibited $\left[\mathrm{M}^{-}\right]$at $m / z 379$ corresponding to molecular formula $\mathrm{C}_{13} \mathrm{H}_{22} \mathrm{~N}_{3} \mathrm{O}_{8} \mathrm{P}$.

The product corresponding to $R_{f} 0.13$ in solvent A was obtained in $51.7 \%$ yield and from UV and electrophoresis data no evidence of base or phosphate alkylation was obtained. The ${ }^{1} \mathrm{H}$ NMR spectrum, however, exhibited a downfield shift of the anomeric proton, which was located at $\delta 6.00$, as compared to the anomeric proton of $5^{\prime}-\mathrm{CMP}$ at $\delta 5.98$; indicating a substitution at $2^{\prime}-\mathrm{OH}$ of ribose. The ethyl signals were located at $\delta 1.18$, a triplet integrating for three protons ascribable for the methyl group and the methylene signal at $\delta 3.65$, a quartet, integrating for two protons. The product was therefore characterized as 2 -O-ethyl-5'-CMP as the disodium salt 7. FAB (negative) mass exhibited the molecular ion $[\mathrm{M}-\mathrm{H}]$ at $m / z 394$ corresponding to molecular formula $\mathrm{C}_{11} \mathrm{H}_{15} \mathrm{~N}_{3} \mathrm{O}_{8} \mathrm{PNa}_{2}$.

The product corresponding to $R_{f} 0.22$ in solvent A was obtained in $5.70 \%$ yield, and indicated an unsubstituted base and phosphate groups. The ${ }^{1} \mathrm{H}$ NMR spectrum exhibited a shift of anomeric proton at $\delta 5.95$, which indicated a substitution of 3'$\mathrm{OH}$ group. Therefore the compound was assigned as $3^{\prime}$-O-ethyl-5'-CMP 8. FAB (negative) mass ex- 
hibited the $[\mathrm{M}-\mathrm{H}]$ at $m / z 350$, corresponding to molecular formula $\mathrm{C}_{11} \mathrm{H}_{17} \mathrm{~N}_{3} \mathrm{O}_{8} \mathrm{P}$.

The reaction of $n$-propyl iodide with $5^{\prime}$-CMP was carried out at $70-75^{\circ} \mathrm{C}$, paper chromatography of the crude reaction mixture showed the formation of three new products of higher $R_{f}$ (Table I) as compared to the starting material. The product of $R_{f} 0.48$ on paper electrophoresis exhibited slower mobility as compared to that of $5^{\prime}$-CMP at $\mathrm{pH} 8$ and its UV spectrum showed a shift of $\lambda_{\max }$ at both acid and basic $\mathrm{pH}$ (Table II) which was of the same order as that of a $\mathrm{N}^{3}$ substituted CMP derivative $[11,12]$. The FAB (negative) mass spectrum exhibited the molecular ion $\left[\mathrm{M}^{-}\right]$at $m / z 429$ corresponding to molecular formula $\mathrm{C}_{15} \mathrm{H}_{25} \mathrm{~N}_{3} \mathrm{O}_{8} \mathrm{PNa}$; indicating the presence of two $n$-propyl groups. On the basis of ${ }^{1} \mathrm{H}$ NMR the second propyl group was assigned on $2^{\prime}-\mathrm{OH}$ as the anomeric proton was shifted downfield at $\delta 6.01$ as compared to $5^{\prime}$-CMP at $\delta 5.98$. The signals for two $\mathrm{CH}_{3}$ groups of the propyl were located at $\delta 0.88$ as two triplets integrating for six protons, a multiplet at $\delta 1.58$ integrating for four protons ascribable to two $\mathrm{CH}_{2}$ groups and a multiplet at $\delta 3.63$ integrating for four protons ascribable to two $\mathrm{OCH}_{2}$ groups. The UV, NMR and FAB spectral evidence led this compound to be characterized as $\mathrm{N}^{3}, 2^{\prime}$ O- $n$-propyl-5'-CMP as the monosodium salt 9.

The product corresponding to $R_{f} 0.45$ in solvent A was obtained in $13.7 \%$ yield, its UV spectrum and electrophoresis showed no substitution at the base or phosphate moieties (Table I, II) while the ${ }^{1} \mathrm{H}$ NMR spectrum indicated the presence of two $n$-propyl groups. Two triplets at $\delta 0.87$ integrating for $6 \mathrm{H}$ and ascribable to two $\mathrm{CH}_{3}$ protons were present. A multiplet at $\delta 1.56$ for $4 \mathrm{H}$ ascribable to protons of two $\mathrm{CH}_{2}$ groups and two triplets at $\delta 3.64$ for $4 \mathrm{H}$ ascribable to the protons of two $\mathrm{O}-\mathrm{CH}_{2}$ groups were also present. The FAB (negative) mass spectrum exhibited the molecular ion $\left[\mathrm{M}^{-}\right]$at $m / z 429$ which corresponded to the molecular formula $\mathrm{C}_{15} \mathrm{H}_{25} \mathrm{~N}_{3} \mathrm{O}_{8} \mathrm{PNa}$; the product was therefore assigned as $2^{\prime}, 3^{\prime}$-Di-O- $n$-propyl-5'-CMP monosodium salt $\mathbf{1 0}$. The compound of $R_{f} 0.12$ in solvent A was obtained in $38.1 \%$ yield. Its UV spectrum as well as electrophoretic mobility was similar to that of 5 -CMP indicating unsubstituted base and phosphate moieties. The ${ }^{1} \mathrm{H}$ NMR spectrum exhibited the anomeric proton at $\delta 6.00$, a downfield shift as compared to $5^{\prime}$-CMP indicating a $2^{\prime}-\mathrm{OH}$ substitution. A triplet at $\delta 0.84$ is ascribable to $\mathrm{CH}_{3}$ protons of $n$-propyl, a sextet at $\delta 1.57$ for $\mathrm{CH}_{2}$ protons and triplet at $\delta 3.61$ for $\mathrm{OCH}_{2}$ protons of the propyl group. FAB (negative) mass spectrum exhibited $m / z 387[\mathrm{M}]^{-}$corresponding to molecular formula $\mathrm{C}_{12} \mathrm{H}_{19} \mathrm{~N}_{3} \mathrm{O}_{8} \mathrm{PNa}$, the compound was therefore assigned as $2^{\prime}-\mathrm{O}-n$-propyl- $5^{\prime}$ CMP as the monosodium salt, $\mathbf{1 1}$. The reaction of 5 -CMP with isopropyl iodide was carried out at $70{ }^{\circ} \mathrm{C}$, the faster moving product of $R_{f} 0.23$ in solvent A was obtained in $11.2 \%$ yield. The UV and electrophoresis (Table I, II) indicated no substitution at base or phosphate portions. The ${ }^{1} \mathrm{H}$ NMR spectrum showed anomeric $\mathrm{H}-1^{\prime}$ signal at $\delta 5.89$, a shift indicating isopropylation at $3^{\prime}-\mathrm{OH}$ group. The isopropyl protons were located at the expected values. A double doublet for $6 \mathrm{H}$ was located at $\delta 1.06$ and was ascribed to two methyls, a multiplet $1 \mathrm{H}$ was located at $\delta 3.64$ and was ascribed to $\mathrm{OCH}$ group. The FAB mass spectrum showed the molecular ion peak [M] ${ }^{-}$at $m / z 409$ corresponding to molecular formula $\mathrm{C}_{12} \mathrm{H}_{18} \mathrm{~N}_{3} \mathrm{O}_{8} \mathrm{PNa}_{2}$ the structure was therefore assigned as $3^{\prime}$-O-isopropyl-5'-CMP disodium salt 12.

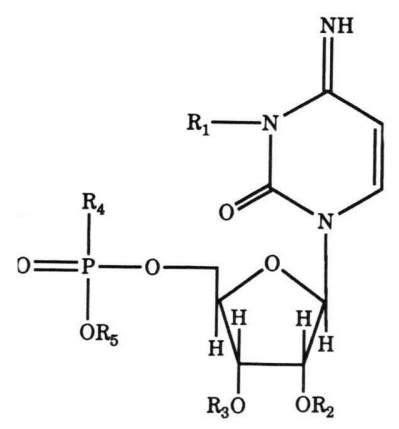

$1 \quad R_{1}=R_{2}=R_{3}=H ; R_{4}=R_{5}=N a$

$2 \mathrm{R}_{1}=\mathrm{CH}_{3} ; \mathrm{R}_{2}=\mathrm{R}_{3}=\mathrm{R}_{4}=\mathrm{R}_{5}=\mathrm{H}$

$3 \mathrm{R}_{1}=\mathrm{H} ; \mathrm{R}_{2}=\mathrm{R}_{3}=\mathrm{CH}_{3} ; \mathrm{R}_{4}=\mathrm{R}_{5}=\mathrm{H}$

$4 \mathrm{R}_{1}=\mathrm{H} ; \mathrm{R}_{2}=\mathrm{CH}_{3} ; \mathrm{R}_{3}=\mathrm{R}_{4}=\mathrm{R}_{5}=\mathrm{H}$

$5 \mathrm{R}_{1}=\mathrm{R}_{2}=\mathrm{H} ; \mathrm{R}_{3}=\mathrm{CH}_{3} ; \mathrm{R}_{4}=\mathrm{R}_{5}=\mathrm{Na}$

$6 \mathrm{R}_{1}=\mathrm{H} ; \mathrm{R}_{2}=\mathrm{R}_{3}=\mathrm{C}_{2} \mathrm{H}_{5} ; \mathrm{R}_{4}=\mathrm{R}_{5}=\mathrm{H}$

$7 \mathrm{R}_{1}=\mathrm{H} ; \mathrm{R}_{2}=\mathrm{C}_{2} \mathrm{H}_{5} ; \mathrm{R}_{3}=\mathrm{H} ; \mathrm{R}_{4}=\mathrm{R}_{5}=\mathrm{Na}$

$8 \mathrm{R}_{1}=\mathrm{R}_{2}=\mathrm{H} ; \mathrm{R}_{3}=\mathrm{C}_{2} \mathrm{H}_{5} ; \mathrm{R}_{4}=\mathrm{R}_{5}=\mathrm{H}$

$9 \mathrm{R}_{1}=\mathrm{R}_{2}=\mathrm{n}-\mathrm{C}_{3} \mathrm{H}_{7} ; \mathrm{R}_{3}=\mathrm{R}_{4}=\mathrm{H} ; \mathrm{R}_{5}=\mathrm{Na}$

$10 \mathrm{R}_{1}=\mathrm{H} ; \mathrm{R}_{2}=\mathrm{R}_{3}=\mathrm{n}-\mathrm{C}_{3} \mathrm{H}_{7} ; \mathrm{R}_{4}=\mathrm{H} ; \mathrm{R}_{5}=\mathrm{Na}$

$11 \mathrm{R}_{1}=\mathrm{H} ; \mathrm{R}_{2}=\mathrm{n}-\mathrm{C}_{3} \mathrm{H}_{7} ; \mathrm{R}_{3}=\mathrm{R}_{4}=\mathrm{H} ; \mathrm{R}_{5}=\mathrm{Na}$

$12 \mathrm{R}_{1}=\mathrm{R}_{2}=\mathrm{H} ; \mathrm{R}_{3}=$ iso $-\mathrm{C}_{3} \mathrm{H}_{7} ; \mathrm{R}_{4}=\mathrm{R}_{5}=\mathrm{Na}$ 
The studies reported above indicate that under strongly alkaline conditions 5'-CMP can be alkylated with alkyl iodides predominantly at the ribose moiety with the 2'-O-alkylated isomers being synthesized in maximal yields. The reaction of isopropyl iodide is interesting as only the 3'-O-isomer was obtained in small yield under our reaction conditions. Molecular models show that the heterocyclic ring will offer substantial steric hindrance to the incoming bulkier isopropyl group at the $2^{\prime}-\mathrm{OH}$ group; the $3^{\prime}-\mathrm{OH}$ group is freely available for the reaction to occur. The smaller yield of the 3'-O-isopropyl derivative may be explained by difficult ionisation of the $3^{\prime}-\mathrm{OH}$ group in the presence of a neighbouring negatively charged phosphate.

\section{Experimental}

Cytidine-5'-monophosphate (5'-CMP) was purchased from BDH, England. Paper chromatography was performed in all glass apparatus in a descending manner using solvent systems, A, Isopropanol: $\mathrm{NH}_{4} \mathrm{OH}: \mathrm{H}_{2} \mathrm{O}(7: 1: 2 \mathrm{v} / \mathrm{v})$; $\mathrm{B}$, Ethanol: $1 \mathrm{M}$ Ammonium acetate, $\mathrm{pH} 7.4(7: 3 \mathrm{v} / \mathrm{v})$ and $\mathrm{C}$, $n$-propanol: $\mathrm{NH}_{4} \mathrm{OH}: \mathrm{H}_{2} \mathrm{O}(55: 10: 35)$. Preparative paper chromatography was carried out on 3 MM Whatman filter sheets. Paper electrophoresis was done on Whatman No.1. paper strips $43.5 \times 8.8 \mathrm{~cm}$ at 400 volts and 18 Amperes for two hours, using buffer I $0.05 \mathrm{M}$ phosphate $\mathrm{pH} 8.0$ and buffer II, $0.025 \mathrm{M}$ sodium acetate $\mathrm{pH} 4.5$.

UV spectral data were obtained on UNICAM SP 500 spectrophotometer and ${ }^{1} \mathrm{H}$ NMR spectra on a BRUKER AM-300 spectrometer. FAB mass spectra in the negative mode were recorded on a Finnigan MAT-312 mass spectrometer connected to a PDP $11 / 34$ computer system. For ${ }^{1} \mathrm{H}$ NMR the concentration of samples was maintained constant as $5 \mathrm{mg} / 0.5 \mathrm{ml}$ solutions in $\mathrm{D}_{2} \mathrm{O}$.

\section{General alkylation procedure}

5 -CMP (500 mg) was dissolved in a mixture of $1 \mathrm{~N}$ sodium hydroxide $(5 \mathrm{ml})$ and 1,4-dioxane $(5 \mathrm{ml})$ and while stirring magnetically the desired alkyl halide $(2 \mathrm{ml})$ was added. Depending upon the alkyl halide the reaction mixture was stirred at room temperature or at elevated temperatures for $3 \mathrm{~h}$ and paper chromatography in solvent $\mathrm{A}, \mathrm{B}$ and $\mathrm{C}$ was carried out to monitor the formation of products.
The crude reaction mixture was concentrated to $2 \mathrm{ml}$ at $37^{\circ} \mathrm{C}$ and was separated by preparative paper chromatography on $3 \mathrm{MM}$ Whatman sheets, using solvent $\mathrm{A}$. The bands corresponding to the products were excised and eluted with distilled water $(80 \mathrm{ml})$. The eluate was evaporated under vacuum and the products were thoroughly dried before making spectral and chromatographic measurements.

The reaction with methyl iodide was carried out at room temperature and resulted into the formation of four new products.

\section{$N^{3}$-Methylcytidine-5'-monophosphate (2)}

The product corresponding to $R_{f} 0.21$ in solvent A (Table I) was obtained as an amorphous powder (98 mg; 18.8\%). - ${ }^{1} \mathrm{H}$ NMR $\left(\mathrm{D}_{2} \mathrm{O}\right)$ exhibited $\delta 8.05(\mathrm{~d}, J=6.9 \mathrm{~Hz} ; 1 \mathrm{H}, \mathrm{H}-6) ; \delta 6.25(\mathrm{~d}, J=$ $6.9 \mathrm{~Hz}, 1 \mathrm{H}, \mathrm{H}-5) ; \delta 6.0\left(\mathrm{~d}, J=3.0 \mathrm{~Hz}, 1 \mathrm{H}, \mathrm{H}-1^{\prime}\right)$ and $\delta 3.32\left(\mathrm{~s}, 3 \mathrm{H}, \mathrm{N}-\mathrm{CH}_{3}\right)$.

\section{2',3'-Di-O-methylcytidine-5'-monophosphate (3)}

The product corresponding to $R_{f} 0.26$ solvent A was an amorphous solid (104 mg; 19.1\%). $-{ }^{1} \mathrm{H}$ NMR $\left(\mathrm{D}_{2} \mathrm{O}\right)$, exhibited signals at $\delta 8.0(\mathrm{~d}, J=$ $8.0 \mathrm{~Hz}, 1 \mathrm{H}, \mathrm{H}-6) ; \delta 6.27$ (d, $J=8.0 \mathrm{~Hz}, 1 \mathrm{H}, \mathrm{H}-5$ ); $\delta 5.98\left(\mathrm{~d}, J=2.5 \mathrm{~Hz}, 1 \mathrm{H}, \mathrm{H}-1^{\prime}\right) ; \delta 3.52(3 \mathrm{H}, \mathrm{s}$, $\left.2^{\prime}-\mathrm{OCH}_{3}\right) ; \delta 3.41\left(\mathrm{~s}, 3 \mathrm{H}, 3^{\prime}-\mathrm{OCH}_{3}\right)$.

FAB (negative ion) mass spectrum exhibited $m / z 350[\mathrm{M}-\mathrm{H}]$ corresponding to molecular formula $\mathrm{C}_{11} \mathrm{H}_{17} \mathrm{~N}_{3} \mathrm{O}_{8} \mathrm{P}, \quad m / z 442 \quad[\mathrm{M}-\mathrm{H}+$ glycerol], $m / z 321\left[\mathrm{M}-2 \times \mathrm{CH}_{3}\right]$.

\section{2'-O-Methylcytidine-5'-monophosphate (4)}

The product corresponding to $R_{f} 0.15$, solvent A was an amorphous powder $(200 \mathrm{mg} ; 38.3 \%)$. ${ }^{1} \mathrm{H}$ NMR $\left(\mathrm{D}_{2} \mathrm{O}\right)$ exhibited $\delta 8.05(\mathrm{~d}, J=8.0 \mathrm{~Hz}$, $1 \mathrm{H}, \mathrm{H}-6) ; \delta 6.20(\mathrm{~d}, J=8.0 \mathrm{~Hz}, 1 \mathrm{H}, \mathrm{H}-5) ; \delta 6.03$ $\left(\mathrm{d}, J=2.5 \mathrm{~Hz}, 1 \mathrm{H}, \mathrm{H}^{\prime} 1^{\prime}\right.$; for CMP $\mathrm{H}-1^{\prime}$ at $\left.\delta 5.98\right)$; $\delta 3.52\left(\mathrm{~s}, 3 \mathrm{H}, 2^{\prime}-\mathrm{OCH}_{3}\right)$.

FAB (negative ion) exhibited $m / z 336[\mathrm{M}-\mathrm{H}]$ corresponding to molecular formula $\mathrm{C}_{10} \mathrm{H}_{15} \mathrm{~N}_{3} \mathrm{O}_{8} \mathrm{P}$; $m / z 428\left[\mathrm{M}-\mathrm{H}+\right.$ glycerol], $m / z 322\left[\mathrm{M}+\mathrm{H}-\mathrm{CH}_{3}\right]$.

\section{3'-O-Methylcytidine-5'-monophosphate disodium salt} (5)

The product of $R_{f} 0.12$ in solvent $\mathrm{A}$ was an amorphous powder $(60 \mathrm{mg} ; 11.5 \%) .-{ }^{1} \mathrm{H}$ NMR $\left(\mathrm{D}_{2} \mathrm{O}\right)$ exhibited signals at $\delta 8.07(\mathrm{~d}, J=7.5 \mathrm{~Hz}$, $1 \mathrm{H}, \mathrm{H}-6) ; \delta 5.98$ (d, $J=7.5 \mathrm{~Hz}, 1 \mathrm{H}, \mathrm{H}-5) ; \delta 5.72$ (d, $\left.J=2.6 \mathrm{~Hz}, 1 \mathrm{H}, \mathrm{H}-1^{\prime}\right) ; \delta 3.42\left(\mathrm{~s}, 3 \mathrm{H}, 3^{\prime}-\mathrm{OCH}_{3}\right)$.

FAB (negative ion) $m / z 380[\mathrm{M}-\mathrm{H}]$ corresponding to molecular formula $\mathrm{C}_{10} \mathrm{H}_{13} \mathrm{~N}_{3} \mathrm{O}_{8} \mathrm{PNa}_{2}$. 


\section{2', 3'-Di-O-ethylcytidine-5'-monophosphate (6)}

The product of $R_{f} 0.71$ in solvent $\mathrm{A}$ was an amorphous solid (124 mg; 21.1\%). - ${ }^{1} \mathrm{H}$ NMR $\left(\mathrm{D}_{2} \mathrm{O}\right)$ exhibited signals at $7.98(\mathrm{~d}, J=8.0 \mathrm{~Hz}, 1 \mathrm{H}$, H-6), $\delta 6.15$ (d, $J=8.0 \mathrm{~Hz}, 1 \mathrm{H}, \mathrm{H}-5) ; \delta 6.02$ (d, $\left.J=3.0 \mathrm{~Hz}, 1 \mathrm{H}, \mathrm{H}-1^{\prime}\right) ; \delta 1.15\left(2 \times \mathrm{t}, 6 \mathrm{H}, 2 \times \mathrm{CH}_{3}\right)$; $\delta 3.65\left(\mathrm{~m}, 4 \mathrm{H}, 2 \times \mathrm{OCH}_{2}\right)$.

FAB (negative ion) mass spectrum exhibited $m / z 379[\mathrm{M}]^{-}$corresponding to molecular formula $\mathrm{C}_{13} \mathrm{H}_{22} \mathrm{~N}_{3} \mathrm{O}_{8} \mathrm{P} ; m / z 470$ [M-H+glycerol].

\section{2'-O-Ethylcytidine-5'-monophosphate disodium salt} (7)

The product had $R_{f} 0.13$ in solvent A $(281 \mathrm{mg}$; $51.7 \%) .-{ }^{1} \mathrm{H}$ NMR $\left(\mathrm{D}_{2} \mathrm{O}\right)$ exhibited signals at $\delta 8.15(\mathrm{~d}, J=8.0 \mathrm{~Hz}, 1 \mathrm{H}, \mathrm{H}-6), \delta 6.15(\mathrm{~d}, J=$ $8.0 \mathrm{~Hz}, 1 \mathrm{H}, \mathrm{H}-5) ; \delta 6.00\left(\mathrm{~d}, J=3.0 \mathrm{~Hz}, 1 \mathrm{H}, \mathrm{H}-1^{\prime}\right)$; $\delta 1.15\left(\mathrm{t}, 3 \mathrm{H}, \mathrm{CH}_{3}\right) ; \delta 3.65\left(\mathrm{q}, 2 \mathrm{H},-\mathrm{OCH}_{2}\right)$.

FAB (negative ion) mass spectrum exhibited $m / z 394[\mathrm{M}-\mathrm{H}]^{-}$corresponding to molecular formula $\mathrm{C}_{11} \mathrm{H}_{15} \mathrm{~N}_{3} \mathrm{O}_{8} \mathrm{PNa}_{2}, m / z 367 \quad\left[\mathrm{M}+\mathrm{H}-\mathrm{C}_{2} \mathrm{H}_{5}\right]$, $m / z 459\left[\mathrm{M}+\mathrm{H}-\mathrm{C}_{2} \mathrm{H}_{5}+\right.$ glycerol] .

\section{3'-O-Ethylcytidine-5'-monophosphate (8)}

The compound showed an $R_{f}$ of 0.22 in solvent A, $(31 \mathrm{mg} ; 5.70 \%) .-{ }^{1} \mathrm{H}$ NMR $\left(\mathrm{D}_{2} \mathrm{O}\right)$ exhibited signals at $\delta 7.93(\mathrm{~d}, J=8.0 \mathrm{~Hz}, 1 \mathrm{H}, \mathrm{H}-6) ; \delta 6.35(\mathrm{~d}$, $J=8.0 \mathrm{~Hz}, 1 \mathrm{H}, \mathrm{H}-5) ; \delta 5.95(\mathrm{~d}, J=3.0 \mathrm{~Hz}, 1 \mathrm{H}$, $\left.\mathrm{H}-1^{\prime}\right) ; \delta 1.15$ (t, $\left.3 \mathrm{H}, \mathrm{CH}_{3}\right) ; \delta 3.65$ (q, $2 \mathrm{H}, \mathrm{OCH}_{2}$ ).

FAB (negative ion) mass spectrum exhibited $m / z 350[\mathrm{M}-\mathrm{H}]$, corresponding to molecular formula $\mathrm{C}_{11} \mathrm{H}_{17} \mathrm{~N}_{3} \mathrm{O}_{8} \mathrm{P}, m / z 442[\mathrm{M}-\mathrm{H}+$ glycerol].

\section{$N^{3}-2^{\prime}-O$-Di-n-propylcytidine-5'-monophosphate monosodium salt $\mathbf{( 9 )}$}

The reaction of $5^{\prime}$-CMP with $n$-propyliodide was carried out at $70{ }^{\circ} \mathrm{C}$ for $3 \mathrm{~h}$. The product corresponding to $R_{f} 0.48$ in solvent A was obtained as an amorphous hygroscopic solid (51 mg; 7.6\%). ${ }^{1} \mathrm{H}$ NMR $\left(\mathrm{D}_{2} \mathrm{O}\right)$ exhibited signals at $\delta 8.11(\mathrm{~d}, J=$ $7.8 \mathrm{~Hz}, 1 \mathrm{H}, \mathrm{H}-6) ; \delta 6.21$ (d, $J=7.8 \mathrm{~Hz}, 1 \mathrm{H}, \mathrm{H}-5$ ); $\delta 6.01\left(\mathrm{~d}, J=3.8 \mathrm{~Hz}, 1 \mathrm{H}, \mathrm{H}-1^{\prime}\right) ; \delta 0.88(2 \times \mathrm{t}, 6 \mathrm{H}$, $\left.2 \times \mathrm{CH}_{3}\right) ; \delta 1.58\left(\mathrm{~m}, 4 \mathrm{H}, 2 \times \mathrm{CH}_{2}\right) ; \delta 3.63(\mathrm{~m}, 4 \mathrm{H}$, $\left.2 \times \mathrm{OCH}_{2}\right)$.

FAB (negative ion) mass spectrum exhibited $m / z 429\left[^{\mathrm{M}}\right]^{-}$corresponding to molecular formula
$\mathrm{C}_{15} \mathrm{H}_{25} \mathrm{~N}_{3} \mathrm{O}_{8} \mathrm{PNa}, \quad m / z 407 \quad[\mathrm{M}+\mathrm{H}-\mathrm{Na}], \quad m / z 499$ [M+H-Na+glycerol], $m / z 521$ [M+glycerol].

\section{2',3'-Di-O-n-propylcytidine-5'-monophosphate monosodium salt (10)}

The product had $R_{f} 0.45$ in solvent $\mathrm{A}$ and was obtained as amorphous powder (91 mg; 13.7\%). ${ }^{1} \mathrm{H}$ NMR $\left(\mathrm{D}_{2} \mathrm{O}\right)$ exhibited $\delta 8.10(\mathrm{~d}, J=8.0 \mathrm{~Hz}$, $1 \mathrm{H}, \mathrm{H}-6) ; \delta 6.16(\mathrm{~d}, J=8.0 \mathrm{~Hz}, 1 \mathrm{H}, \mathrm{H}-5) ; \delta 5.99$ $\left(\mathrm{d}, J=3.4 \mathrm{~Hz}, 1 \mathrm{H}, \mathrm{H}-1^{\prime}\right) ; \delta 0.87(2 \times \mathrm{t}, 6 \mathrm{H}$, $\left.2 \times \mathrm{CH}_{3}\right) ; \delta 1.56\left(\mathrm{~m}, 4 \mathrm{H}, 2 \times \mathrm{CH}_{2}\right) ; \delta 3.64(2 \times \mathrm{t}, 4 \mathrm{H}$, $\mathrm{O}-\mathrm{CH}_{2}$ ).

$\mathrm{FAB}$ (negative ion) mass spectrum showed $\left[\mathrm{M}^{-}\right]$ at $m / z 429$, corresponding to molecular formula $\mathrm{C}_{15} \mathrm{H}_{25} \mathrm{~N}_{3} \mathrm{O}_{8} \mathrm{PNa} ; m / z 407$ [M+H-Na], $m / z 386$ [M-n-propyl], $m / z 343$ [M-2n-propyl], $m / z 521$ [M+glycerol].

\section{2'-O-n-propylcytidine-5'-monophosphate mono- sodium salt (11)}

The product showed $R_{f} 0.12$ in solvent $\mathrm{A}$, (229 mg; 38.1\%). - ${ }^{1} \mathrm{H}$ NMR $\left(\mathrm{D}_{2} \mathrm{O}\right)$ exhibited $\delta 8.11(\mathrm{~d}, J=7.0 \mathrm{~Hz}, 1 \mathrm{H}, \mathrm{H}-6) ; \delta 6.00(\mathrm{~d}, J=$ $7.0 \mathrm{~Hz}, 1 \mathrm{H}, \mathrm{H}-5) ; \delta 6.00\left(\mathrm{~d}, J=3.0 \mathrm{~Hz}, 1 \mathrm{H}, \mathrm{H}-1^{\prime}\right)$; $\delta 0.84\left(3 \mathrm{H}, \mathrm{t}, \mathrm{CH}_{3}\right) ; \delta 1.57$ (sextet, $\left.2 \mathrm{H}, \mathrm{CH}_{2}\right)$; $\delta 3.61\left(\mathrm{t}, 2 \mathrm{H}, \mathrm{OCH}_{2}\right)$.

FAB (negative ion) mass spectrum exhibited $m / z 387[\mathrm{M}]^{-}$, corresponding to molecular formula $\mathrm{C}_{12} \mathrm{H}_{19} \mathrm{~N}_{3} \mathrm{O}_{8} \mathrm{PNa} ; m / z 343$ [M-H-alkyl]; $m / z 365$ [M+H-Na] and $m / z 479$ [M+glycerol].

\section{3'-O-Isopropylcytidine-5'-monophosphate disodium salt (12)}

The reaction with isopropyliodide was carried out at $70{ }^{\circ} \mathrm{C}$, the product corresponding to $R_{f} 0.23$ in solvent A was a brownish powder $(71.5 \mathrm{mg}$; $14.3 \%) .-{ }^{1} \mathrm{H}$ NMR $\left(\mathrm{D}_{2} \mathrm{O}\right)$ exhibited $\delta 7.98(\mathrm{~d}, J=$ $7.8 \mathrm{~Hz}, 1 \mathrm{H}, \mathrm{H}-6) ; \delta 5.96(\mathrm{~d}, J=7.8 \mathrm{~Hz}, 1 \mathrm{H}, \mathrm{H}-5)$; $\delta 5.89\left(\mathrm{~d}, J=4.2 \mathrm{~Hz}, 1 \mathrm{H}, \mathrm{H}-1^{\prime}\right), \delta 1.06(\mathrm{dd}, 6 \mathrm{H}$, $\left.\left(\mathrm{CH}_{3}\right)_{2}\right) ; \delta 3.64(\mathrm{~m}, 1 \mathrm{H},>\mathrm{CHO})$.

FAB (negative ion) mass spectrum exhibited $m / z 409[\mathrm{M}]^{-}$corresponding to molecular formula $\mathrm{C}_{12} \mathrm{H}_{18} \mathrm{~N}_{3} \mathrm{O}_{8} \mathrm{PNa}_{2} ; m / z 387[\mathrm{M}+\mathrm{H}-\mathrm{Na}] ; m / z 365$ $[\mathrm{M}+2 \mathrm{H}-2 \times \mathrm{Na}] ; \quad m / z 344 \quad[\mathrm{M}+\mathrm{H}$-alkyl-Na]; $\mathrm{m} / z 501[\mathrm{M}+$ glycerol]; $\mathrm{m} / \mathrm{z} 593$ [M+2× glycerol]. 
[1] R. H. Hall, The Modified Nucleosides in Nucleic Acids, Columbia Press, New York (1971).

[2] G. P. Wheeler, Cancer Res. 22, 651 (1962).

[3] E. Farber, Adv. Cancer Res. 7, 383 (1963).

[4] B. J. Ortwerth and G. D. Novelli, Cancer Res. 29, 381 (1969).

[5] F. Rottman and K. Heinlein, Biochemistry 7, 2634 (1968).

[6] K. A. Khan and F. Rottman, Fed. Europ. Biochem. Soc. FEBS Letters 28, 25 (1972).

[7] F. Rottman, K. Frederici, P. Comstock, and K. A. Khan, Biochemistry 13, 2762 (1974).

[8] H. Inoue, Y. Hayase, A. Imura, S. Iwai, K. Miura, and E. Ohtsuka, Nucl. Acid. Res. 15(15) 6131 (1987).

[9] I. Tazawa, S. Tazawa, J. L. Alderfer, and P. O. P. T'so, Biochemistry 11, 4931 (1972).
[10] M. Ikehara and S. Uesugi, Tetrahedron 28, 3687 (1973)

[11] J. A. Haines, C. B. Rees, and A. Todd, J. Chem. Soc. 1964, 1406.

[12] R. L. C. Brimacombe and C. B. Reese, J. Chem. Soc. (C), 1966, 588

[13] P. Brookes and P. D. Lawley, J. Chem. Soc. 1962, 1384.

[14] A. D. Broom, M. P. Schweizer, and P. O. P. T'so, J. Am. Chem. Soc. 89, 3612 (1967).

[15] B. E. Griffin and C. B. Reese, Biochim. Biophys. Acta 68, 185 (1963).

[16] J. T. Kusmierek, J. Giziewickz, and D. Shugar, Biochemistry 12, 194 (1973).

[17] A. M. Hogg, J. G. Kelland, J. C. Vederas, and C. Tamm, Helv. Chim. Acta 69, 908 (1986). 